\title{
Shading and electric performance of a prototype greenhouse blind system based on semi-transparent photovoltaic technology
}

\author{
Zhi Li ${ }^{\mathrm{a}}$, Akira YAno ${ }^{\mathrm{b}, \uparrow}$, Marco Cossu ${ }^{\mathrm{b}}$, Hidekazu YoshiOKA ${ }^{\mathrm{b}}$, Ichiro KITA ${ }^{\mathrm{b}}$ and Yasuomi IBARAKI $^{\mathrm{c}}$ \\ ( ${ }^{\mathrm{a}}$ The United Graduate School of Agricultural Sciences, Tottori University, 4-101 Koyama-Minami, Tottori, Tottori 680-8553, Japan ) \\ ${ }^{\mathrm{b}}$ Faculty of Life and Environmental Science, Shimane University, 1060 Nishikawatsu, Matsue, Shimane 690-8504, Japan \\ ${ }^{\mathrm{c}}$ Faculty of Agriculture, Yamaguchi University, 1677-1 Yoshida, Yamaguchi, Yamaguchi 753-8515, Japan
}

\begin{abstract}
Photovoltaic (PV) energy is emerging in the greenhouse industry to compensate energy demands for cultivation. Because both crops and PVs need sunlight, their compatibility on the same land unit often conflicts. To overcome this difficulty, we prototyped a venetian-blind-type shading system comprising semi-transparent bifacial PV modules that concurrently function for greenhouse shading control and electricity production. The PV blind installed in a test greenhouse was operated automatically according to the external solar irradiance. When the solar irradiance was higher than a predetermined threshold level, the PV modules were oriented parallel to the roof with sunlight shading of $42 \%$. The PV modules were oriented to be perpendicular to the roof when the irradiance level was low, prioritizing the sunlight intake into the greenhouse. The blind system operations were managed completely by the electrical energy generated by the PV modules. Actually, the PV-produced electricity was surplus to the blind system operations, suggesting that additional greenhouse appliances can be operated by the PV-produced electricity. This system might be applicable to greenhouses in high-insolation regions as an energetically stand-alone dynamic shading system to produce a better light environment for crops.
\end{abstract}

Key words: Irradiance; Renewable energy; Solar cell; Stand-alone; Venetian blind

\section{Introduction}

Shading plays an important role for crop cultivation in greenhouses, particularly during summer (Hanan, 1998; Ishii et al., 2001; Castilla, 2013; Martínez et al., 2016). Appropriate shading mitigates the excessive temperature rise which can occur in greenhouses (Yano et al., 2007; García et al., 2011; López-Marín et al., 2012). It can also contribute to the improvement of crop growth and development (Lorenzo et al., 2003; Dai et al., 2009; Kittas et al., 2009; Deng et al., 2012), as well as extension of the culture period and regulation of ripening (Teitel and Segal, 1995). Practical and inexpensive means of providing greenhouse shading commonly involve nets or reflective coatings (Hanan 1998; García et al., 2011; López-Marín et al., 2012; Castilla, 2013). Actually, these simple shading methods are beneficial. The sunlight on the canopy is moderated properly by virtue of the reflection of partial sunlight to the outside. Nevertheless, the sunlight energy is not exploited completely in a greenhouse with such conventional shading methods.

The use of photovoltaic (PV) systems is emerging in the greenhouse industry to mitigate fossil fuel dependence. Installing PV modules on part of the greenhouse roof area can be a strategy when crops require moderate shading in high-insolation regions. Unlike simple shading nets or reflective coatings, appropriate shading and electricity production can be realized concurrently in a greenhouse with installed PV. However, excessive shading

\footnotetext{
Received; December 25, 2017

Accepted; May 10, 2018

†Corresponding Author: yano@life.shimane-u.ac.jp

DOI: 10.2480/agrmet.D-17-00047
}

by enlarged PV panels on the greenhouse roof conflicts with the sunlight requirements of crops below (Castellano, 2014; Cossu et al., 2014; Castellano et al., 2016; Cossu et al., 2017). Accordingly, some works have been undertaken to improve light transmittance of PV installed roofs by contriving the shapes or arrangement of PV panels (Yano et al., 2010; Kadowaki et al., 2012; Pérez-Alonso et al., 2012; Tani et al., 2014; Yano et al., 2014; Fatnassi et al., 2015; Buttaro et al., 2016; Cossu et al., 2016). In this way, inhibitory effects of shading on crop growth can be mitigated (Kadowaki et al., 2012; Ureña-Sánchez et al., 2012; Tani et al., 2014; Buttaro et al., 2016).

Another concept related to the application of PVs to greenhouses is the separate use of wavelength ranges of the solar radiation spectrum for cultivation and for electrical energy generation. Sonneveld et al. (2010a; 2010b) developed and assessed a PV system based on this concept. In their systems, photosynthetically active radiation (PAR) is delivered into the greenhouse. Near infrared radiation (NIR) is reflected on a straight focal line above the concavely curved roof, the surface of which was coated with NIR reflective film. The PV modules positioned on the focal facing downward can receive the concentrated NIR and can generate electricity. The cooling load in the greenhouse can thus be reduced by the NIR reflection. Exploiting translucent organic solar cells on the greenhouse roof represents another solution based on use of separate sunlight spectrum components for electricity generation and crop cultivation (Emmott et al., 2015; Yang et al., 2015).

Another system was developed using a greenhouse roof made with Fresnel lenses to collect direct sunlight onto PV modules to generate electricity and to use scattered sunlight for crop production (Souliotis et al., 2006; Sonneveld et al., 2011; Hemming et al., 2014). Recently, new ideas have been proposed 
to regulate irradiance in greenhouses dynamically using PV blind systems (Vadiee and Martin, 2014; Marucci et al., 2015; Marucci and Cappuccini, 2016a, 2016b; Vadiee and Yaghoubi, 2016), although improvement of the blind mechanism and shading controllability is expected.

Applications of PVs on portions of the greenhouse roofs enable moderate shading and electricity production on the same land unit, as summarized above. However, most of them are ineluctable to shade crops from low level sunlight unnecessarily during winter or cloudy days. This problem was implied by Tani et al. (2014), who reported that the dry weight accumulation of lettuce plants grown under partial PV cover was unaffected during summer and autumn, but suppressed in winter.

For this study, we prototyped a venetian-blind-type greenhouse shading system that incorporates bifacial semi-transparent PV-modules as blind blades. The system changes the PV module inclination autonomously according to the solar irradiance level. The blind control system orients the PV modules to make them parallel to the greenhouse roof to generate electricity with moderate shading when solar irradiance is intense or to make them perpendicular to the roof when the irradiance level is low. Thereby, solar irradiance intake in the greenhouse is ensured during cloudy days or low-insolation times. Moreover, this stand-alone system was operated using electricity generated by the PV blind itself. Details of the prototype PV blind system are reported herein along with data supporting the validity of the shading and electricity-producing performance.

\section{Materials and methods}

\subsection{Bifacial semi-transparent PV module as a venetian-blind blade for greenhouse shading application}

The bifacial semi-transparent PV-module (Fig. 1a) used as a blind blade was $500 \mathrm{~mm} \times 200 \mathrm{~mm} \times 11 \mathrm{~mm}$, weighing $2.23 \mathrm{~kg}$. The module structure comprised three layers sandwiching $3.0-\mathrm{mm}$ thick resin between two 3.8-mm-thick glass plates. In transparent resin, 13,764 mono-crystalline-silicon PV cells with 1.2-mm-diameter (Sphelar ${ }^{\circledR}$; Sphelar Power Corp., Kyoto, Japan) were embedded with conductor wires connecting the cells. Between the $0.38 \mathrm{~mm}$-wide and 0.1-mm-wide conductors, PV cells were aligned (Fig. 1b). Each cell consisted of a p-type semiconductor inner sphere and an n-type semiconductor outer shell. The PV cells were spherical, enabling them to generate electrical energy using sunlight from all directions (Biancardo et al., 2007; Taira and Nakata, 2010; Yano et al., 2014; Cossu et al., 2016). The produced electricity was drawn from electrodes in contact with the respective semiconductor types (Fig. 1b). The

(a)

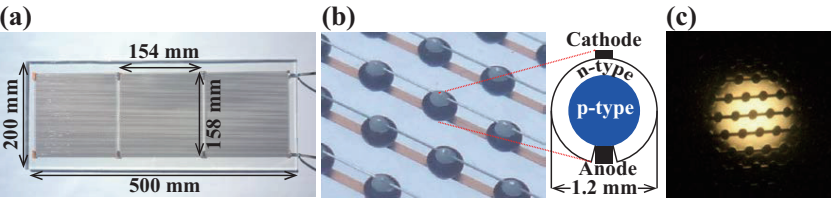

Fig. 1. Semi-transparent PV module as a venetian-blind blade for the greenhouse shading application: overview of the PV module (a), cross-sectional structure of the spherical Si-PV cell (b), overlap of the sun and the PV cells photographed using a digital camera with a solar eclipse observation filter $1 \mathrm{~m}$ below the module (c). spherical PV cell is smaller than the apparent diameter of the sun seen from an observer below the PV module. Therefore, the PV cells cannot eclipse the direct solar radiation completely (Fig. 1c). The rated output power of the PV module was $1.2 \mathrm{~W}\left(1 \mathrm{~kW} \mathrm{~m}^{-2}\right.$ single side irradiation at $25^{\circ} \mathrm{C}$ with air mass 1.5$)$. The percentage of the opaque area, which included the $0.38 \mathrm{~mm}$ width conductors and the cells, was $31 \%$ when the module was visible from the direction of the module normal. This percentage corresponds to the ideal value with a perfect transparency of the glass plates and resin.

The PV module rim was covered by a 2 -mm-thick aluminum frame. Iron shafts were fixed respectively to the two short sides of the module frame to rotate the PV module around the shaft axis (Fig. 2). Two PV modules were aligned on the common rotation axis and were mounted on a $1250 \mathrm{~mm} \times 825 \mathrm{~mm}$ aluminum frame. Only two PV modules were manufactured for this study because of the difficulty of hand assembly of the unique PV module and the consequently high manufacturing costs. Their electrical output terminals were connected in parallel. The module shaft was connected to a geared DC motor (SS23F-LH-860-DC12V; Sawamura Denki Ind. Co., Ltd., Kanagawa, Japan) with rated voltage, current, torque, and rotation speed of $12 \mathrm{~V}, 0.3 \mathrm{~A}, 2.0 \mathrm{~N} \mathrm{~m}$, and $4 \mathrm{rpm}$, respectively. Two pyranometers $\mathrm{P}_{\mathrm{PVT}}$ and $\mathrm{P}_{\mathrm{PVB}}$ (ML-01; Eko Instruments Co. Ltd., Tokyo, Japan) were positioned proximally at the bottom long side of one $\mathrm{PV}$ module. The $\mathrm{P}_{\mathrm{PVT}}$ normal coincided with the PV module normal. The $\mathrm{P}_{\mathrm{PVB}}$ faced $180^{\circ}$ opposite. The global irradiances on the top surface $I_{\mathrm{PVT}}$ and on the bottom surface $I_{\mathrm{PVB}}$ of the $\mathrm{PV}$ modules were measured respectively by $\mathrm{P}_{\mathrm{PVT}}$ and $\mathrm{P}_{\mathrm{PVB}}$. A pyranometer $\mathrm{P}_{\text {Cell }}$ was positioned $0.2 \mathrm{~m}$ below the $\mathrm{PV}$ module, facing the eastern sky with its normal direction aligned to the normal of the eastern roof of a north-south oriented greenhouse, to measure the sunlight shading percentage of the semi-transparent PV module. The distance of $0.2 \mathrm{~m}$ was chosen to avoid collision of $\mathrm{P}_{\text {Cell }}$ and the PV module during module rotation and to ensure positioning of $\mathrm{P}_{\text {Cell }}$ in the PV module shadow when the sun was in the eastern sky.

\subsection{Motor drive circuit for PV-blind rotation control}

A motor drive circuit was developed to rotate the PV modules in response to irradiance (Fig. 3). A pyranometer $\mathrm{P}_{\text {SIGNAL }}$ (ML-01)

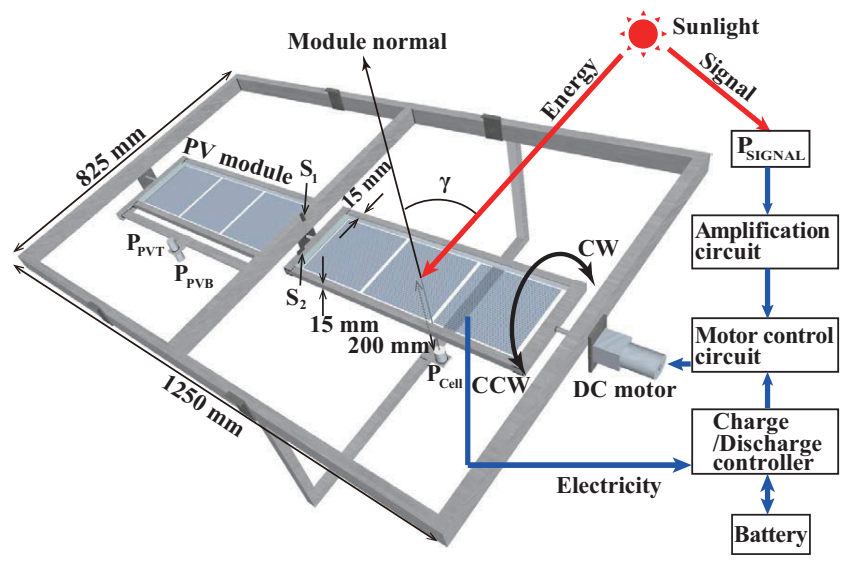

Fig. 2. Block diagram of the prototype $P V$ blind system: $P_{P V T}$ and $\mathrm{P}_{\mathrm{PVB}}$ are pyranometers respectively facing to the sky and the ground when the PV module is set parallel to the greenhouse roof. $S_{1}$ and $S_{2}$ are mechanical switches to stop the blind position at a parallel $\left(S_{2}\right)$ or perpendicular $\left(S_{1}\right)$ position. 
transformed horizontal global irradiance $I_{\mathrm{H}}$ into the input signal voltage of the motor drive circuit. $\mathrm{P}_{\text {SIGNAL }}$ was positioned at the top of the greenhouse. The $\mathrm{P}_{\text {SIGNAL }}$ voltage was amplified linearly using an operational amplifier (LM358; Texas Instruments Inc., Texas, USA). The output voltage of the operational amplifier was voltage $V_{\mathrm{CW}}$ at the $\mathrm{IN}_{1}$ terminal of a DC motor full bridge driver (TA7267BP; Toshiba Corp., Tokyo, Japan). Therefore, $V_{\mathrm{CW}}$ was proportional to $I_{\mathrm{H}}$. The amplification factor can be regulated by an $R_{0}$ value. The motor rotation direction can be changed according to the amplitude balance of the voltages at the input terminals $\mathrm{IN}_{1}\left(V_{\mathrm{CW}}\right)$ and $\mathrm{IN}_{2}\left(V_{\mathrm{CCW}}\right)$ of the DC motor full bridge driver. The $\mathrm{PV}$ blind rotation from the perpendicular to the parallel position to the roof surface was defined as clockwise $(\mathrm{CW})$. The reverse rotation was defined as counter-clockwise $(\mathrm{CCW})$. The $R_{0}$ value determines a threshold irradiance value of the $\mathrm{CW}$ blind rotation.

Two diodes $\mathrm{D}_{1}$ and $\mathrm{D}_{2}$ (BY329-1200; NXP Semiconductors, Eindhoven, The Netherlands) and two mechanical switches $S_{1}$ and $\mathrm{S}_{2}$ (DB1C-A1LB; Cherry GmbH, Auerbach, Germany) were used to achieve automatic reshuffling rotations $\mathrm{CW}$ and $\mathrm{CCW}$ (Fig. 2). $S_{1}$ and $S_{2}$ were installed respectively at the perpendicular and parallel positions relative to the roof surface (Fig. 2). When the PV module touched one of the switches, the motor was disconnected from the circuit and was stopped. When $V_{\mathrm{CW}}>V_{\mathrm{CCW}}$, motor current $i_{\mathrm{M}}$ was supplied from terminal $\mathrm{OUT}_{1}$ of the full bridge driver, then passed $\mathrm{D}_{2}, \mathrm{~S}_{2}$, the motor, and finally arrived at terminal $\mathrm{OUT}_{2}$. The motor rotated the PV module CW during this process. Subsequently, the motor was disconnected from the circuit when the PV module touched $\mathrm{S}_{2}$. Thereby, the PV module stopped at the position parallel to the roof (Fig. 4a). By contrast, when $V_{\mathrm{CCW}}>V_{\mathrm{CW}}$, a reversed current $-i_{\mathrm{M}}$ flowed. Thereby, the PV module turned to the position perpendicular to the roof (Fig. 4b). A voltage gap separating the $\mathrm{CW}$ and $\mathrm{CCW}$ rotations existed to avoid motor rotation instability in the proximity of the threshold $I_{\mathrm{H}}$. This function was included in the DC-motor full-bridge driver (TA7267BP).

The terminals of the motor control circuit, a 28 Ah battery (40B19R; Panasonic Inc., Osaka, Japan), and the PV modules were connected with a charge-discharge controller (SA-MN05-8; Denryo Co. Ltd., Tokyo, Japan) to complete the stand-alone power system (Fig. 2).

A MOS FET relay (G3VM-21AR; Omron Corp., Kyoto, Japan) was added at the drive circuit inlet to eliminate the standby energy consumption of the motor drive circuit during nighttime. The relay was operated according to the experimental

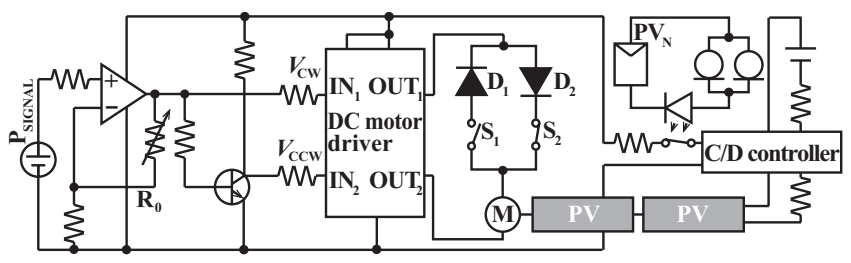

Fig. 3. DC motor control circuit for rotating the semi-transparent PV modules: $\mathrm{M}$ denotes the DC motor; charge-discharge is abbreviated to $\mathrm{C} / \mathrm{D}$. $\mathrm{PV}_{\mathrm{N}}$ denotes a conventional $\mathrm{PV}$ module used for detecting the test site brightness to disconnect the control circuit from the charge-discharge controller during nighttime, thereby reducing the standby energy loss. site brightness, which was monitored by the output current of an additional PV module (KD03; Kyocera Corp., Kyoto, Japan; $\mathrm{PV}_{\mathrm{N}}$ in Fig. 3) with current-regulating diodes.

\subsection{Verification of $P V$ blind performance at the test greenhouse}

The PV blind was installed underneath the east-sky-facing glass roof (tilt angle of $26.5^{\circ}$ ) of the north-south oriented greenhouse $(8.20 \mathrm{~m} \times 4.25 \mathrm{~m})$ at the Shimane University campus $\left(35^{\circ} 29^{\prime} \mathrm{N}, 133^{\circ} 04^{\prime} \mathrm{E}\right)$ (Fig. 4). It was positioned below the roof because the prototype system was not water resistant. The north end of the long axis of the north-south oriented greenhouse deviated $6^{\circ}$ to the west. The greenhouse floor was concrete without crop cultivation. The $0.1 \mathrm{~mm}$ conductor was positioned on the upper side of the PV module, with the $0.38 \mathrm{~mm}$ conductor positioned on the bottom side (see Fig. 1b) when the PV module was parallel to the roof. The external horizontal global-irradiance $I_{\mathrm{H}}$ was measured using pyranometer $\mathrm{P}_{\mathrm{H}}$ (ML-01). Pyranometer $\mathrm{P}_{\mathrm{T}}$ (ML-01) was used to measure the global irradiance on the inclined greenhouse roof-surface $I_{\mathrm{T}}\left(26.5^{\circ}\right.$ inclination and $6^{\circ}$ to the north from true east). $\mathrm{P}_{\mathrm{H}}, \mathrm{P}_{\mathrm{T}}$, and $\mathrm{P}_{\text {SIGNAL }}$ were positioned on the top of the greenhouse roof at $3.5 \mathrm{~m}$ height. The $\mathrm{CW}$ threshold $I_{\mathrm{H}}$ was set at $500 \mathrm{~W} \mathrm{~m}^{-2}$ by adjusting the $\mathrm{R}_{0}$ value at $3 \mathrm{k} \Omega$.

The irradiance, the electrical power output, and the operations of the PV blind were measured at 1 min intervals during 26-29 April and 1-8 May 2017 using a data acquisition unit (34972A; Keysight Technologies Inc., California, USA) and a voltage and current source/meter (6241A; ADC Corp., Tokyo, Japan). Data were stored in a computer after transmission through a GPIB interface. Data obtained during two sunny days (28 April and 4 May) and one cloudy day (26 April) are presented in the results section to demonstrate the electrical and shading performance of the PV blind system.
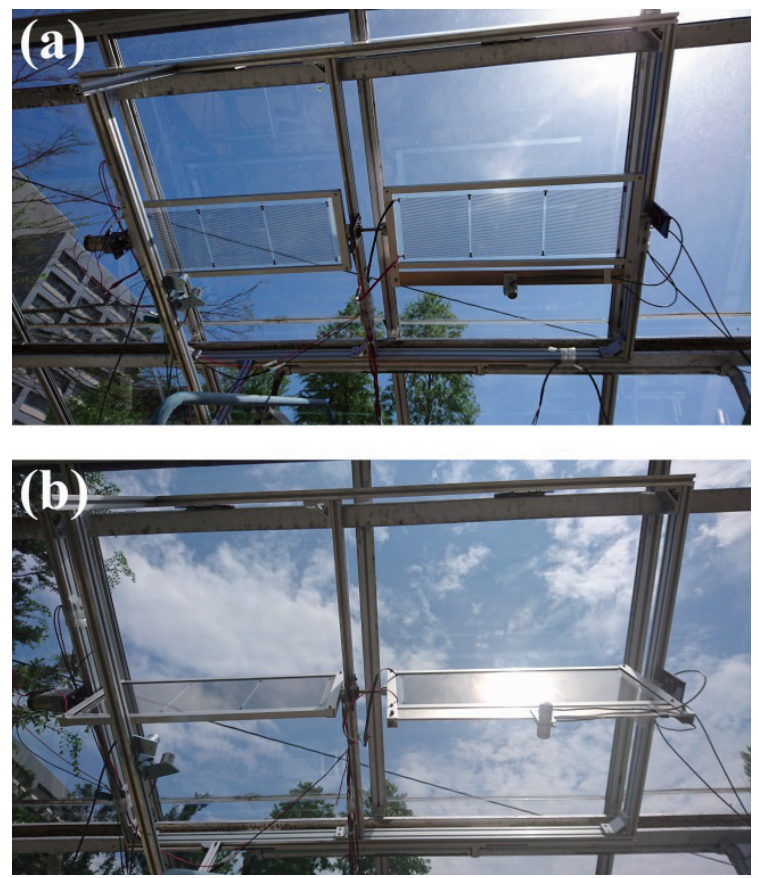

Fig. 4. Semi-transparent PV modules installed underneath the greenhouse glass roof facing the eastern sky: PV modules positioned as parallel (a) or perpendicular (b) to the roof surface. 
The angle $\gamma$ between direct sunlight incidence and the PV-module's normal (Fig. 2) was calculated using the following geometric formula (Yano et al., 2009).

$$
\cos \gamma=\sin h \cos \varphi+\cos h \sin \varphi \cos (|\alpha-\beta|)
$$

In that equation, $h, \varphi, \alpha$, and $\beta$ respectively represent the solar altitude, the PV module tilt angle, the azimuth of the sun, and the azimuth of the PV module normal.

\subsection{Energy balance of the PV blind system}

The energy flow of the PV blind system was measured continuously from 21 February through 23 April 2017. The $\mathrm{CW}$ threshold $I_{\mathrm{H}}$ was set at $600 \mathrm{~W} \mathrm{~m}^{-2}$. Three shunt resistors of $0.1 \Omega$ were connected respectively to the PV module, the battery, and the load terminals of the charge-discharge controller (SA-MN05-8) to measure the PV generated current $i_{\mathrm{PV}}$, the charging current into the battery $i_{\mathrm{C}}$, and the current supply to the motor drive circuit $i_{\mathrm{D}}$. In addition to the current values, $I_{\mathrm{H}}$, $I_{\mathrm{T}}, I_{\mathrm{PVT}}, I_{\mathrm{PVB}}$, as well as voltages at the PV module, battery, and circuit terminals were measured at $10 \mathrm{~s}$ intervals using the data acquisition unit (34972A). By integrating the product of the voltage, current, and duration, the respective cumulative energies generated by the PV module $E_{\mathrm{PV}}$, charged into the battery $E_{\mathrm{C}}$, and supplied to the motor drive circuit $E_{\mathrm{D}}$ were calculated. The total cumulative energy consumption $E_{\mathrm{i}}$ at the charge-discharge controller, conducting wires, shunt resistances, and the internal resistance of the battery were calculated using the following formula.

$$
E_{\mathrm{i}}=E_{\mathrm{PV}}-E_{\mathrm{C}}-E_{\mathrm{D}}
$$

\section{Results}

\subsection{Shading performance of the PV blind}

The global irradiance on the eastern greenhouse roof-surface $I_{\mathrm{T}}$, the global irradiances on the PV top surface $I_{\mathrm{PVT}}$ and on the PV bottom surface $I_{\mathrm{PVB}}$, and the irradiance $I_{\text {Cell }}$ measured by the pyranometer $\mathrm{P}_{\text {Cell }}$ behind the PV module on 28 April and 4 May sunny days are depicted in Figs. 5a and 5b. Morning data of 28 April were lost because of a data-logging computer freeze. $I_{\mathrm{T}}$ peaked before 11:00. $I_{\mathrm{PVT}}$ generally followed the course of $I_{\mathrm{T}}$ with slightly attenuated values according to partial sunlight scattering at the greenhouse glazing. $I_{\mathrm{PVT}}$ was greater than $I_{\mathrm{PVB}}$ during most of the daytime, but $I_{\mathrm{PVB}}$ sharply increased in the late afternoon when the PV modules turned to the position perpendicular to the roof. Thereby, the angle $\gamma$ values jumped up (Figs. 5d and 5e). Direct sunlight irradiated the bottom of the PV module and therefore also irradiated the pyranometer $\mathrm{P}_{\mathrm{PVB}}$ from the western sky at that time. $\mathrm{P}_{\text {Cell }}$ was shaded by the semi-transparent area $(154 \mathrm{~mm} \times 158 \mathrm{~mm}$ square area presented in Fig. 1a) of the PV module from 8:40 to $11: 20$. Direct sunlight reached $\mathrm{P}_{\text {Cell }}$ without passing through the $\mathrm{PV}$ module for the remaining hours. $I_{\text {Cell }}$ decreased sharply when the metal roof beams of the greenhouse or the aluminum PV-module rim blocked the direct sunlight from reaching the $\mathrm{P}_{\text {Cell }}$. The sunlight transmittance of the greenhouse roof glass was calculated using the values of $I_{\mathrm{PVT}}$ over $I_{\mathrm{T}}$ when the PV modules positioned parallel to the roof and the pyranometer $\mathrm{P}_{\mathrm{PVT}}$ were not shaded by any metal frame during 9:00-11:00. The average sunlight transmittance of the greenhouse glass roof was $91 \%$ (Table 1). The sunlight shading percentage of the PV module was calculated from $I_{\text {Cell }}$ over $I_{\mathrm{PVT}}$ during 9:00-11:00. The average sunlight shading was $42 \%$ (i.e. transmittance of $58 \%$, Table 1). During the period, the angle $\gamma$ between the PV module normal and incident direct sunlight was $20^{\circ}-25^{\circ}$ on 28 April (Fig. $5 \mathrm{~d}$ ) and $18^{\circ}-23^{\circ}$ on 4 May (Fig. 5e). $I_{\text {Cell }}$ over $I_{\mathrm{T}}$ during 9:00-11:00 presents the total transmittance of the solar irradiance by the greenhouse glazing and the PV blind (Fig. $5 \mathrm{~g}$ ). The average value of $I_{\text {Cell }} / I_{\mathrm{T}}$ was $53 \%$ (Table 1). This value estimates the transmittance of irradiance to be reached at canopy level when numerous PV modules cover the entire greenhouse roof at the inclination parallel to the roof. When the PV blind was perpendicular to the roof, the direct sunlight was mostly unaffected by the PV blind. Thereby, $I_{\text {Cell }} / I_{\mathrm{T}}$ can be approximated as $90 \%$ according to the transmittance of the greenhouse glazing. This condition was observable during $6: 54-7: 45$ on 4 May, as presented in Fig. 5 b.

On 26 April, a cloudy day (Fig. 5c), the PV blind mostly retained at the perpendicular angle to the roof to prioritize the sunlight intake into the greenhouse. The sky condition was overcast throughout the day. Therefore, direct sunlight was unavailable. At 13:59 the PV blind rotated $\mathrm{CW}$ to the parallel position to the roof. The average $I_{\text {Cell }} / I_{\mathrm{T}}$ during $14: 00-15: 10$ was $45 \%$ (Fig. 5h, Table 1) when the PV blind was parallel to the roof (Fig. 5f). The shading performance of that period approximates a cloudy-day sunlight level in the test greenhouse, the roof of which is assumed to be covered entirely with the semi-transparent PV modules at the parallel inclination to the roof. Before and after the period, $I_{\text {Cell }} / I_{\mathrm{T}}$ were greater than $60 \%$ (Fig. $5 \mathrm{~h}$ ) by virtue of the perpendicular orientation of the PV blades.

\subsection{Electrical characteristics of the PV modules}

The power output $P_{\mathrm{o}}$ of the twin PV modules under the greenhouse glazing measured at 1 min intervals on 28 April and 4 May are depicted in Figs. 6a and 6b. The maximum value of $P_{\mathrm{o}}$ was $2.04 \mathrm{~W}$ at $10: 39$ on 28 April. The $P_{\mathrm{o}}$ curve generally followed the course of bifacial incident irradiance $I_{\mathrm{PVT}}+I_{\mathrm{PVB}}$, but it was suppressed around the peak of $I_{\mathrm{PVT}}+I_{\mathrm{PVB}}$ (Figs. 6a and $6 \mathrm{~b}$ ) because of the PV module microstructure. The spherical cells were interconnected by conductor wires (Fig. 1b) positioned at the top and bottom surface sides of the PV module. The top wires shaded the cells from sunlight irradiating from the top of the PV modules when the module normal was directed to the sun in the eastern sky. Thereby, $P_{\mathrm{o}}$ was suppressed around the peak of $I_{\mathrm{PVT}}+I_{\mathrm{PVB}}$.

The PV module efficiency $\eta$ was calculated using the value of $P_{\mathrm{o}}$ per two-PV module single-side-areas $(500 \mathrm{~mm} \times 200 \mathrm{~mm} \times 2)$ over $I_{\mathrm{PVT}}+I_{\mathrm{PVB}}$ (Fig. 6c). The greenhouse metal beams sometimes

Table 1. Sunlight transmittance of the PV blind and greenhouse glazing.

\begin{tabular}{lcccc}
\hline \multicolumn{5}{l}{ Table 1. Sunlight transmittance of the PV blind and greenhouse glazing. } \\
\hline PV blind & Greenhouse glazing & PV blind + Greenhouse glazing (sunny) & PV blind + Greenhouse glazing (overcast) \\
\hline Sunlight transmittance (\%) & 58 & 91 & 53 & 45
\end{tabular}




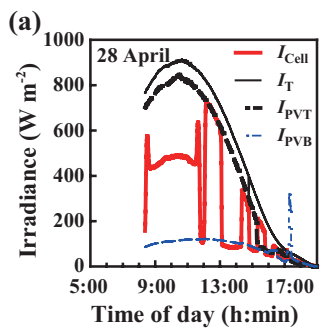

(d)
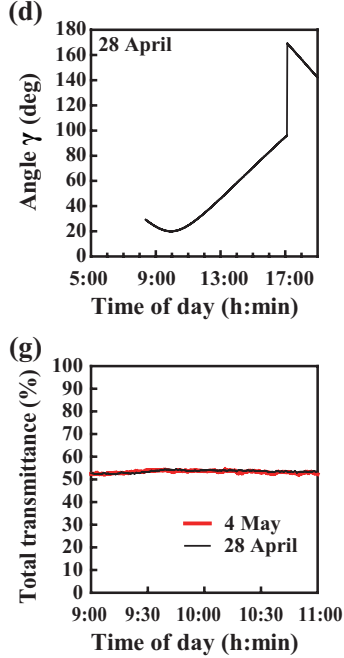
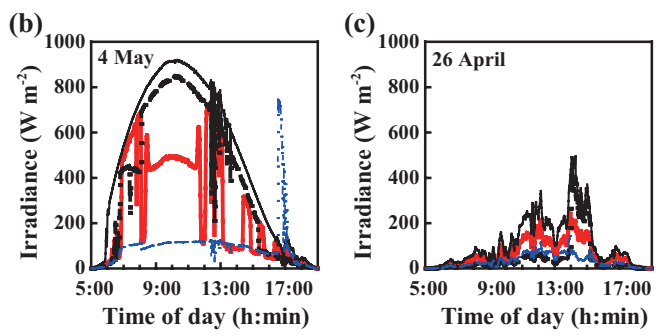

(e)

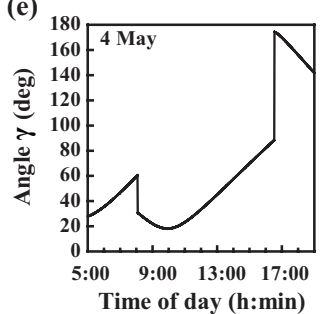

(f)

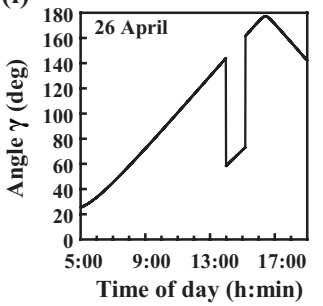

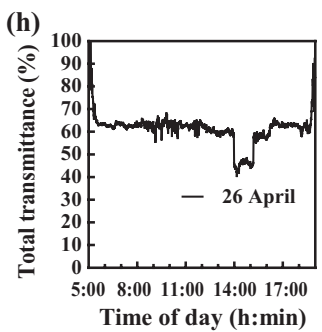

Fig. 5. Global irradiance on the easterly inclined greenhouse roof-surface $I_{\mathrm{T}}$, global irradiances on the PV top surface $I_{\mathrm{PVT}}$ and on the PV bottom surface $I_{\mathrm{PVB}}$, and irradiance behind the PV module $I_{\text {Cell }}$ on 28 April (a), 4 May (b), and 26 April (c); angle $\gamma$ between direct sunlight incidence and the PV module normal on 28 April (d), 4 May (e), and 26 April (f); total transmittance of greenhouse glass and the PV module on sunny days (g, 28 April and 4 May) and on a cloudy day (h, 26 April).

separately shaded $\mathrm{P}_{\mathrm{PVT}}, \mathrm{P}_{\mathrm{PVB}}$, and $\mathrm{PV}$ modules as the sun position moved from east to west. Efficiency $\eta$ decreased sharply when only the PV module was in beam shadow, and increased sharply when only the pyranometers were in shadow. For example, $\eta$ decreased suddenly at $14: 16$ on 28 April and at $14: 20$ on 4 May (Fig. 6c). At the times of those events, $P_{\mathrm{o}}$ dropped suddenly while $I_{\mathrm{PVT}}+I_{\mathrm{PVB}}$ retained the slope of the continuous curve (Figs. $6 \mathrm{a}$ and $6 \mathrm{~b}$ ). Only the PV module was shaded by the greenhouse beam during those events. The average $\eta$ during 9:00-14:00, when direct sunlight impinged on the PV modules and the pyranometers were not shaded by any opaque structure, was $1.1 \%$ on both 28 April and 4 May. The relation between $\eta$ and $\gamma$ during 9:00-14:00 is depicted in Fig. 6d. The values of $\eta$ were greater than $1 \%$ over the wide incident angle of direct sunlight.

\subsection{Energy balance of the PV blind system}

The PV blind operated without outage for two months during 21 February to 23 April (Figs. 7a and 7b). The PV modules rotated 391 times in the $\mathrm{CW}$ direction when $I_{\mathrm{H}}=657.7 \pm$ $159.2 \mathrm{~W} \mathrm{~m}^{-2}$ (mean \pm standard deviation), and 391 times in the CCW direction when $I_{\mathrm{H}}=249.9 \pm 47.0 \mathrm{~W} \mathrm{~m}^{-2}$. On sunny days such as 3, 4, and 23 April, the PV blind operated once CW in the morning and once $\mathrm{CCW}$ in the late afternoon. On heavily cloudy days such as 23 February, 21 and 31 March, 6, 9, 11, and 17 April, the PV modules did not rotate, but instead retained their position perpendicular to the roof, that enabled a better sunlight passage into the greenhouse.

The cumulative energy generated by the PV module $E_{\mathrm{PV}}$,


Fig. 6. Power output $P_{\mathrm{o}}$ curves of the twin PV modules installed underneath the greenhouse roof, horizontal global irradiance $I_{\mathrm{H}}$, and total PV incident irradiance $I_{\mathrm{PVT}}+I_{\mathrm{PVB}}$ measured on 28 April (a) and 4 May (b). Module efficiencies $\eta$ calculated based on $I_{\mathrm{PVT}}$ $+I_{\mathrm{PVB}}$ (c) and relation between $\gamma$ and $\eta$ during 9:00-14:00 (d).

supplied to the motor drive circuit $E_{\mathrm{D}}$, charged into the battery $E_{\mathrm{C}}$, and the internally dissipated energy $E_{\mathrm{i}}$ were, respectively, $1257.5 \mathrm{~kJ}, 998.6 \mathrm{~kJ}, 207.5 \mathrm{~kJ}$, and $51.4 \mathrm{~kJ}$ at the end of the operation test (Fig. 7c). $E_{\mathrm{i}}$ was $0.83 \mathrm{~kJ} \mathrm{~d}^{-1}$ almost constantly. The daytime average current of the motor drive circuit $i_{\mathrm{D}}$ was 0.03 A. The system operation was supported by the energy 
stored preliminarily in the battery during February through 22 March. At the maximum discharge $\left(E_{\mathrm{C}}=-39.0 \mathrm{~kJ}\right)$ on 10 March, $3.2 \%$ of the battery full capacity ( $28 \mathrm{Ah})$ had been discharged. The battery capacity recovered after the day. Finally, surplus electrical energy $E_{\mathrm{C}}=+207.5 \mathrm{~kJ}$ was stored.

\section{Discussion}

The prototype PV blind system operated reliably and continuously in response to the sunlight levels for two months. The operations were automatic and energetically stand-alone. Sunny-day intense sunlight was attenuated under the PV blind according to the semi-transparency of the PV modules. Because of its photovoltaic effect, some of the blocked sunlight by the PV cells was converted into electricity, unlike conventional shading materials such as nets or paint. The PV-produced electrical energy ensured the operation of the blind system. The PV blind had produced $207.5 \mathrm{~kJ}$ of surplus electrical energy by the end of the two-month test. System operations were supported by the energy stored preliminarily in the battery in late winter. At the maximum discharge, the battery supported the system operation using $3.2 \%$ (=0.9 Ah) of the full battery capacity (28 Ah). The results suggest that sufficient energy should be stored in the battery before winter to ensure annual operation.

The annual energy balance of the PV blind system operation was estimated using the experimental data and local meteorological statistics. The orientation of the greenhouse's long axis was regarded as exactly the north-south. The roof was assumed to be covered with replications of the PV blind system installed underneath the glazing roof. For that estimation, the cumulative energy consumption at the motor drive circuit $E_{\mathrm{D}}$ was calculated using the values of motor drive-circuit current $i_{\mathrm{D}}=0.03 \mathrm{~A}$ and voltage of $12 \mathrm{~V}$ during daytime (sunrise and sunset time data from National Astronomical Observatory of Japan). In addition, $E_{\mathrm{i}}=0.5 \mathrm{kWh} \mathrm{m}^{-2} \mathrm{yr}^{-1}$ was determined from experimentally obtained data. Accordingly, the annual energy consumption of the PV blind system per unit of greenhouse area was estimated as $9.4 \mathrm{kWh} \mathrm{m}^{-2} \mathrm{yr}^{-1}\left(=E_{\mathrm{D}}+E_{\mathrm{i}}\right)$. On the other hand, the cumulative electrical energy production of the PV blind was estimated based on local insolation data obtained during the prior 9 years (2009-2017, from Japan Meteorological Agency) and exterior sunlight to electrical energy conversion efficiency $\eta_{0}$ of the PV blind installed underneath the greenhouse roof. The value of $\eta_{0}$ was determined from the equation 3 according to the percentage of the integrated PV-generated electrical energy against the integrated sunlight energy received by the greenhouse ground area of the PV-blind horizontal occupation $\left(S_{\mathrm{PV}} \cos 26.5^{\circ}\right)$.

$$
\eta_{0}=\frac{\int_{21 \mathrm{Feb}}^{23 \mathrm{Apr}} P_{\mathrm{o}} \mathrm{d} t}{S_{\mathrm{PV}} \cos 26.5^{\circ} \int_{21 \mathrm{Feb}}^{23 \mathrm{Apr}} I_{\mathrm{H}} \mathrm{d} t} \times 100 \%=0.88 \%
$$

In this formula, $S_{\mathrm{PV}}$ represents the PV blind area $\left(0.2 \mathrm{~m}^{2}\right)$. The value of $\eta_{0}(=0.88 \%)$ represents the realistic efficiency of the PV blind because both $P_{\mathrm{o}}$ and $I_{\mathrm{H}}$ were experimentally obtained throughout the test period under actual sunlight affected by the greenhouse structure and surrounding university buildings. The calculated value of the annual electrical energy production per unit of greenhouse area was $11.4 \mathrm{kWh} \mathrm{m}^{-2} \mathrm{yr}^{-1}$. The cumulative

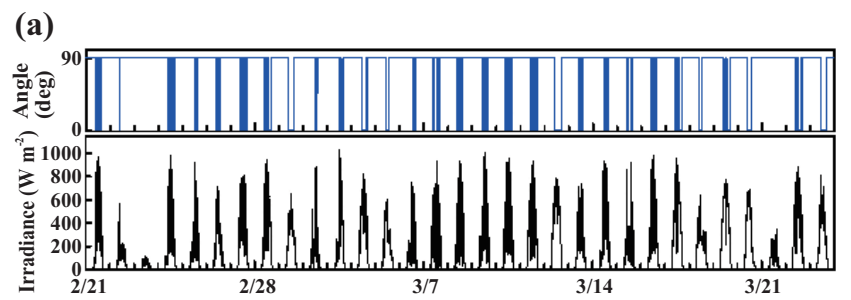

(b)

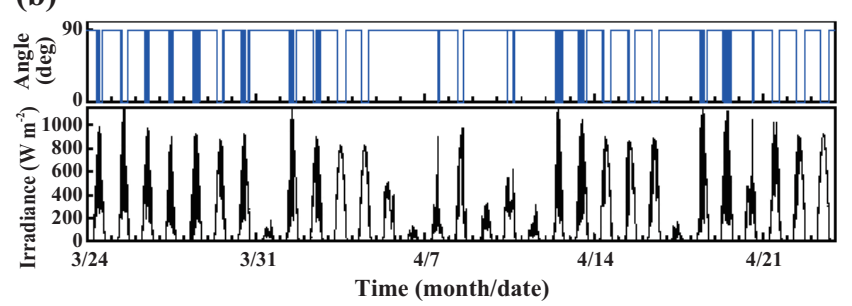

(c)

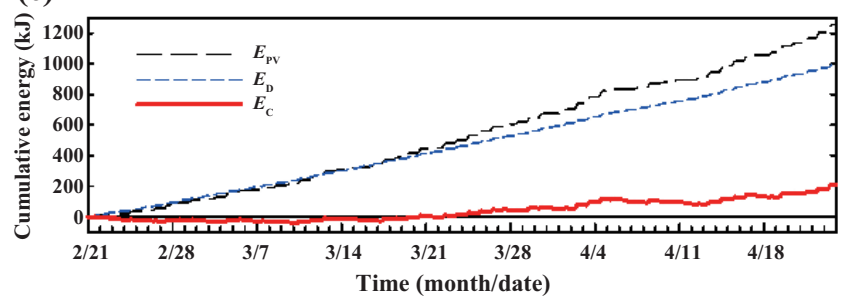

Fig. 7. Horizontal global irradiance $I_{\mathrm{H}}$ and the angle between roof surface and PV module's surface (a, 21 February-23 March; b, 24 March-23 April); cumulative energies generated by the PV module $E_{\mathrm{PV}}$, charged into the battery $E_{\mathrm{C}}$, and supplied to the motor drive circuit $E_{\mathrm{D}}(\mathrm{c})$.

amount of charging capacity was calculated from the difference of the produced and consumed electrical energy (Fig. 8). It was also depicted equivalently as surplus electrical energy per unit greenhouse area $\left(\mathrm{kWh} \mathrm{m}^{-2}\right)$. The surplus electrical energy can be estimated as $2.0 \mathrm{kWh} \mathrm{m}^{-2} \mathrm{yr}^{-1}\left(=11.4-9.4 \mathrm{kWh} \mathrm{m}^{-2} \mathrm{yr}^{-1}\right)$. Therefore, some additional greenhouse power demands can be met using this electrical energy. Campiotti et al. (2008) reported that electrical energy demands range from $2 \mathrm{kWh} \mathrm{m}^{-2} \mathrm{yr}^{-1}$ for very low-technology climate control to a maximum of $9 \mathrm{kWh} \mathrm{m}^{-2} \mathrm{yr}^{-1}$ with advanced climate control (heating, cooling or ventilation) in Mediterranean greenhouses. Sato et al. (2013) investigated the electrical energy demands of a heat pump and an oil-fired heater in a $1000 \mathrm{~m}^{2}$ rose greenhouse in Shizuoka, Japan. According to their report, 3.43 and $0.37 \mathrm{kWh} \mathrm{m}^{-2} \mathrm{yr}^{-1}$ (12.34 and $1.32 \mathrm{MJ} \mathrm{m}^{-2} \mathrm{yr}^{-1}$ ) of electrical energy were demanded respectively for heating and cooling by the heat pump. Also, $0.31 \mathrm{kWh} \mathrm{m}^{-2} \mathrm{yr}^{-1}\left(1.13 \mathrm{MJ} \mathrm{m}^{-2} \mathrm{yr}^{-1}\right)$ of electrical energy was demanded by the oil-fired heater. The surplus of electrical energy $\left(2.0 \mathrm{kWh} \mathrm{m}^{-2} \mathrm{yr}^{-1}\right)$ producible by the present PV system would meet the electrical energy demands for the Mediterranean greenhouses with simpler controls or exceed the demands of the heat pump cooling and the oil-fired heater used in the study by Sato et al., if the present PV blinds could cover the entire greenhouse.

The low energy efficiency of the PV module is ascribed to the low PV-cell density that was intended to ensure adequate sunlight transmissivity to the crops below the PV module. To overcome this conflict of electrical energy production and sunlight transmissivity, increasing the PV cell density, decreasing the conductor wire width, 
and increasing the transparency of the conductor wire (Dalapati et al., 2018) remain as topics to be tackled in future.

On sunny days the greenhouse interior irradiance was maintained as around $500 \mathrm{~W} \mathrm{~m}^{-2}$ when the exterior irradiance was greater than $800 \mathrm{~W} \mathrm{~m}^{-2}$ (Figs. 5a and 5b). For the natural sunlight spectrum, $500 \mathrm{~W} \mathrm{~m}^{-2}$ is approximated as $900 \mu \mathrm{mol} \mathrm{m} \mathrm{m}^{-2} \mathrm{~s}^{-1}$ of photosynthetic photon flux density (PPFD) (Larcher, 1995). PPFD exceeds $2000 \mu \mathrm{mol} \mathrm{m} \mathrm{m}^{-2} \mathrm{~s}^{-1}$ on sunny summer days, although the photosynthetic light saturation points of major agricultural C3 plants are $1000-1500 \mu \mathrm{mol} \mathrm{m} \mathrm{m}^{-2} \mathrm{~s}^{-1}$ (Larcher, 1995) or less $(\mathrm{Fu}$ et al., 2012; Hidaka et al., 2013). The yield and quality of some crop species might be improved if only excessive sunlight were moderately shaded by the semi-transparent PV blinds, which can be rotated to a less-shading position when irradiance is less than a photosynthetically optimal level. Based on their data obtained from well-designed experiments, Kläring and Krumbein (2013) reported that the quality of tomato fruit might be unaffected by partial shading if shading were to occur only during high irradiation hours. López-Marín et al. (2013) reported that some sweet pepper crops in Spain might be producible under $40 \%$ shading. High-quality rocket was cultivated in Italy with PV panel installation on $32 \%$ of the greenhouse roof (Buttaro et al., 2016). Tani et al. (2014) demonstrated that lettuce can be cultivated appropriately under $50 \%$ solar cell coverage of a greenhouse roof during summer and autumn in Japan. They used light-scattering film underneath the PV cells, which were arranged in a checkerboard formation on the test greenhouse. The lettuce plants received $700 \mu \mathrm{mol} \mathrm{m} \mathrm{m}^{-2} \mathrm{~s}^{-1}$ of PPFD at the peak on 4 September. These results of earlier studies show that the present dynamic blind control with less than $42 \%$ shading of the PV modules might be beneficial for greenhouse cultivation of moderate-light demand crops in high-insolation seasons or regions.

Cloudy day irradiance was adequately introduced into the greenhouse by virtue of the blind orientation to the perpendicular position relative to the roof. This improvement of the sunlight intake

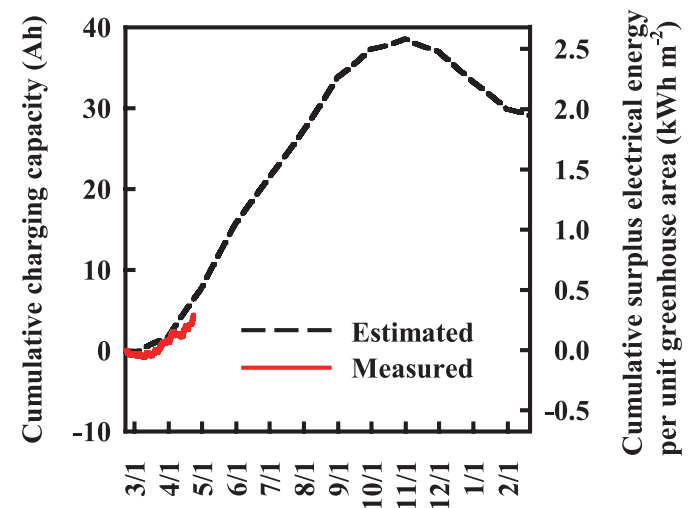

Time (month/date)

Fig. 8. Calculated annual cumulative charging capacity (left ordinate axis) and cumulative surplus electrical energy of the PV module blinds per unit greenhouse area (right ordinate axis) estimated based on local meteorological data. The surplus electrical energy of $2.0 \mathrm{kWh} \mathrm{m}^{-2} \mathrm{yr}^{-1}$ corresponds to the subtraction of the system consumed energy of $9.4 \mathrm{kWh} \mathrm{m}^{-2} \mathrm{yr}^{-1}$ from the PV generated energy of $11.4 \mathrm{kWh} \mathrm{m}^{-2} \mathrm{yr}^{-1}$. The battery charging capacity of the PV blind system measured from 21 February to 23 April is also depicted. in the greenhouse on cloudy days is a particular advantage of this PV blind system. As depicted in Figs. 7a and 7b, the PV blind retained a perpendicular $\left(\theta=90^{\circ}\right)$ position relative to the roof without any rotation on overcast days. This behavior is also beneficial for conserving electrical energy consumption by the blind operations.

Sunlight energy received at the ground level at the center in the greenhouse, the roof of which was covered with the replication of the PV blinds, was estimated assuming two different blind angles $\left(\theta=0^{\circ}\right.$ and $\left.90^{\circ}\right)$ using exterior $I_{\mathrm{H}}$ data measured on 4 May (Fig. 9). The values reported in Table 1 were used as the sunlight transmittance of glazing and the PV blind. The atmospheric transmittance during the day was determined as 0.65 . The sunlight energy in the test greenhouse was estimated to be $20.6 \mathrm{MJ} \mathrm{m}^{-2} \mathrm{~d}^{-1}$ without the PV blinds (Fig. 9 a and b). It
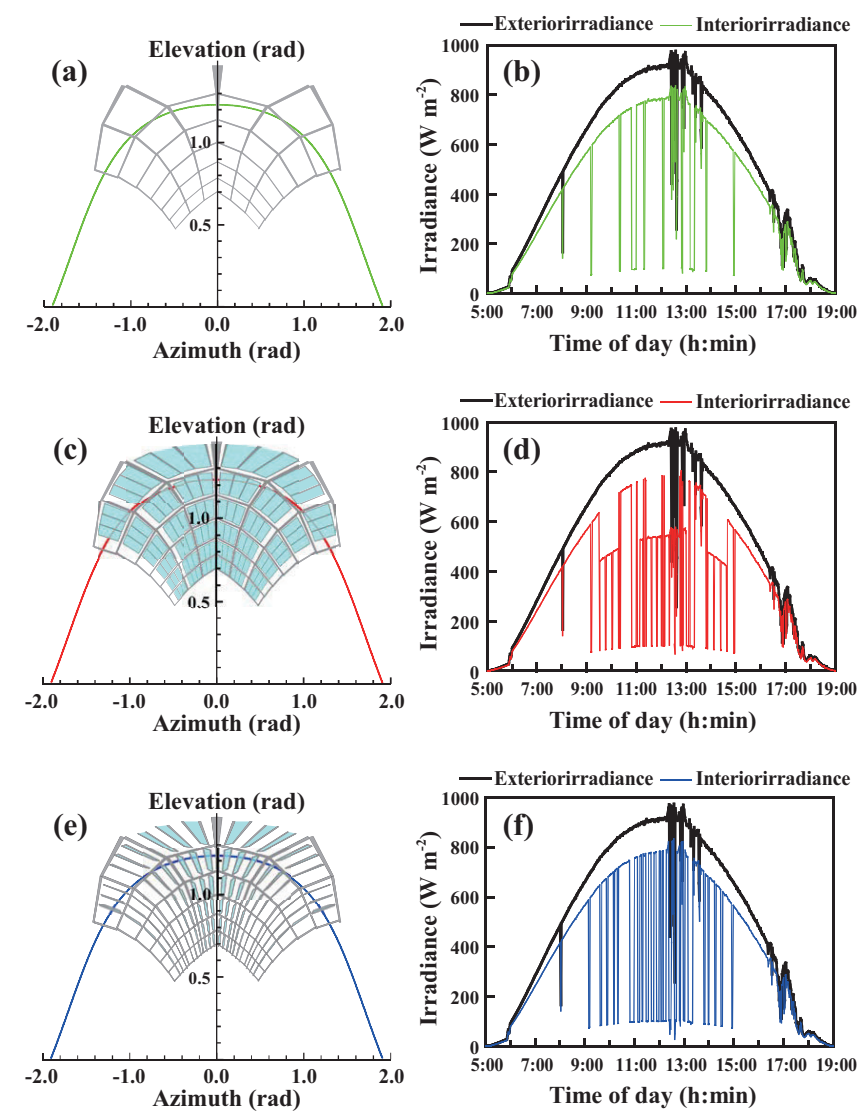

Fig. 9. Estimated greenhouse interior irradiance on 4 May assuming that the PV blinds were not installed ( $a, b)$ or the greenhouse roof was covered with the semi-transparent PV blinds, the tilt angle of which were parallel $\left(\theta=0^{\circ} ; \mathrm{c}, \mathrm{d}\right)$ or perpendicular $\left(\theta=90^{\circ} ; \mathrm{e}, \mathrm{f}\right)$ to the roof. Exterior horizontal global irradiance $I_{\mathrm{H}}$ measured on 4 May is depicted with black bold lines (b, d, and f). Numerous gray lines in (a), (c), and (e) represent opaque frames $(5 \mathrm{~cm}$ width of north-south oriented beams and $4 \mathrm{~cm}$ width of east-west oriented beams) of the greenhouse roof and the PV blind rim superimposed on the angular coordinate of the sun path (green line in (a), red line in (c), and blue line in (e)). The observation point of the sun path was set at the center of the greenhouse on the floor level. A positive azimuth corresponds to a western direction. The azimuth at 0 rad indicates the true south. Sky blue areas in (c) and (e) represent the semi-transparent PV blinds. Calculated interior irradiances under the respective PV blind conditions are depicted with green (b), red (d), and blue (f) lines. 
would be $17.0 \mathrm{MJ} \mathrm{m}^{-2} \mathrm{~d}^{-1}$ if the PV blinds were oriented at $\theta=0^{\circ}$ (Fig. $9 \mathrm{c}$ and d). The interior sunlight energy would be increased to 18.1 $\mathrm{MJ} \mathrm{m}^{-2} \mathrm{~d}^{-1}$ if the PV blinds were kept at $\theta=90^{\circ}$ to prioritize sunlight intake into the greenhouse (Fig. 9 e and f).

This study confirmed the physical feasibility of a PV blind system for greenhouse applications. Although the shading controllability presents new possibilities of greenhouse environment control, the small scale of the prototype is insufficient for deployment to conventional greenhouses. To extend the system scale, the cost of manufacturing specific semi-transparent PV modules represents the salient difficulty. There are some possibilities to design a semi-transparent PV blind using substitute PV cells through low-cost automated manufacturing processes. The glass plates used in the present PV modules were superior in terms of transparency, thermal stability and mechanical hardness. These characteristics were necessary to fabricate the special semi-transparent PV modules. However, gaining this benefit necessitated the sacrifice of light weight. The weight restricts the number of PV modules that are controllable by a single motor. The lighter the weight is, the more connectable PV modules are controllable by a single motor, which boosts the energy efficiency of the total blind system. Substituting the module matrix material from glass to plastic might reduce weight and costs considerably. Further studies should be conducted to attract agricultural and industrial attention to greenhouse applications of PV systems and to achieve benefits for large-scale production of greenhouse PV materials.

\section{Conclusions}

For application to greenhouse shading, a stand-alone venetian-blind-type system was prototyped using bifacial semi-transparent PV modules. The maximum power output of the twin PV modules was $2 \mathrm{~W}$ when they were operated underneath the greenhouse glazing roof. The sunlight-to-electricity conversion efficiency of the PV module was $1.1 \%$ based on the reference area of the PV module single-side, $69 \%$ of which was transparent material to transmit sufficient sunlight to the greenhouse. The stand-alone PV blind system was operated autonomously according to the level of the external irradiance. The PV modules were oriented parallel to the greenhouse roof with $42 \%$ sunlight shading when the irradiance was intense. When the irradiance level was low, the PV modules were oriented perpendicular to the roof to increase the sunlight intake into the greenhouse. The cumulative energy balance of the PV blind system became positive after a two-month test of operation conducted during early spring in Japan, suggesting that the surplus energy can be supplied to electrical appliances for greenhouse environment control to achieve better crop yield and quality. Further studies must be undertaken to expand the blind coverage area to some model experimental greenhouses and to test plant reactions to a modified light environment.

\section{Acknowledgments}

This study was supported by JSPS KAKENHI (Grant Nos. 26•04085 and (C) 15K07667). The authors thank Sphelar Power Corporation (Kyoto, Japan) for fabricating the semi-transparent PV modules. We thank Prof. Makoto Ueno of Shimane
University for permission to use the greenhouse. We also thank Mr. Yasunori Katsumata and Mr. Tetsuo Matsuoka of Shimane University for their assistance during basic experiments.

\section{References}

Biancardo M, Taira K, Kogo N, Kikuchi H, Kumagai N, Kuratani $\mathrm{N}$, Inagawa I, Imoto S, Nakata J, 2007: Characterization of microspherical semi-transparent solar cells and modules. Solar Energy 81, 711-716.

Buttaro D, Renna M, Gerardi C, Blando F, Santamaria P, Serio F, 2016: Soilless production of wild rocket as affected by greenhouse coverage with photovoltaic modules. Acta Scientiarum Polonorum Hortorum Cultus 15, 129-142.

Campiotti C, Dondi F, Genovese A, Alonzo G, Catanese V, Incrocci L, Bibbiani C, 2008: Photovoltaic as sustainable energy for greenhouse and closed plant production system. Acta Horticulturae 797, 373-378.

Castellano S, 2014: Photovoltaic greenhouses: evaluation of shading effect and its influence on agricultural performances. Journal of Agricultural Engineering XLV:433, 168-175.

Castellano S, Santamaria P, Serio F, 2016: Solar radiation distribution inside a monospan greenhouse with the roof entirely covered by photovoltaic panels. Journal of Agricultural Engineering XLVII:485, 1-6.

Castilla N, 2013: Greenhouse Technology and Management (2nd edition), CAB International, Oxfordshire, pp. 1-335.

Cossu M, Ledda L, Urracci G, Sirigu A, Cossu A, Murgia L, Pazzona A, Yano A, 2017: An algorithm for the calculation of the light distribution in photovoltaic greenhouses. Solar Energy 141, 38-48.

Cossu M, Murgia L, Ledda L, Deligios PA, Sirigu A, Chessa F, Pazzona A, 2014: Solar radiation distribution inside a greenhouse with south-oriented photovoltaic roofs and effects on crop productivity. Applied Energy 133, 89-100.

Cossu M, Yano A, Li Z, Onoe M, Nakamura H, Matsumoto T, Nakata J, 2016: Advances on the semi-transparent modules based on micro solar cells: First integration in a greenhouse system. Applied Energy 162, 1042-1051.

Dai Y, Shen Z, Liu Y, Wang L, Hannaway D, Lu H, 2009: Effects of shade treatments on the photosynthetic capacity, chlorophyll fluorescence, and chlorophyll content of Tetrastigma hemsleyanum Diels et Gilg. Environmental and Experimental Botany 65, 177-182.

Dalapati GK, Kushwaha AK, Sharma M, Suresh V, Shannigrahi S, Zhuk S, Masudy-Panah S, 2018: Transparent heat regulating (THR) materials and coatings for energy saving window applications: Impact of materials design, micro-structural, and interface quality on the THR performance. Progress in Materials Science 95, 42-131.

Deng Y, Li C, Shao Q, Ye X, She J, 2012: Differential responses of double petal and multi petal jasmine to shading: I Photosynthetic characteristics and chloroplast ultrastructure. Plant Physiology and Biochemistry 55, 93-102.

Emmott CJM, Röhr JA, Campoy-Quiles M, Kirchartz T, Urbina A, Ekins-Daukes NJ, Nelson J, 2015: Organic photovoltaic greenhouses: a unique application for semi-transparent PV? Energy \& Environmental Science 8, 1317-1328.

Fatnassi H, Poncet C, Bazzano MM, Brun R, Bertin N, 2015: A numerical simulation of the photovoltaic greenhouse microclimate. Solar Energy 120, 575-584.

Fu W, Li P, Wu Y, 2012: Effects of different light intensities on 
chlorophyll fluorescence characteristics and yield in lettuce. Scientia Horticulturae 135, 45-51.

García ML, Medrano E, Sánchez-Guerrero MC, Lorenzo P, 2011: Climatic effects of two cooling systems in greenhouses in the Mediterranean area: External mobile shading and fog system. Biosystems Engineering 108, 133-143.

Hanan JJ, 1998: Greenhouses: Advanced Technology for Protected Horticulture. CRC Press, Boca Raton, pp. 1-684.

Hemming S, de Zwart HF, Swinkels GLAM, Janssen HJJ, 2014: Development of electricity producing greenhouses - two case studies. Acta Horticulturae 1037, 129-136.

Hidaka K, Dan K, Imamura H, Miyoshi Y, Takayama T, Sameshima K, Kitano M, Okimura M, 2013: Effect of supplemental lighting from different light sources on growth and yield of strawberry. Environmental Control in Biology 51, 41-47.

Ishii M, Maruo T, Ito T, Sase S, Okushima R, 2001: Human thermal comfort and plant productivity in protected horticulture-Environmental analysis of decrease light intensity and temperature in the summer-. Environmental Control in Biology 39, 9-16.

Japan Meteorological Agency, Monthly mean global solar radiation, http://www.data.jma.go.jp/obd/stats/etrn/view/monthly_s3_en.php? block no $=47741 \&$ view $=11$ (accessed 13 March 2018)

Kadowaki M, Yano A, Ishizu F, Tanaka T, Noda S, 2012: Effects of greenhouse photovoltaic array shading on Welsh onion growth. Biosystems Engineering 111(3), 290-297.

Kittas C, Rigakis N, Katsoulas N, 2009: Influence of shading screens on microclimate, growth and productivity of tomato. Acta Horticulturae 807, 97-102.

Kläring H-P, Krumbein A, 2013: The effect of constraining the intensity of solar radiation on the photosynthesis, growth, yield and product quality of tomato. Journal of Agronomy and Crop Science 199, 351-359.

Larcher W, 1995: Physiological Plant Ecology (3rd edition). Springer-Verlag, Heidelberg, pp. 1-506.

Lorenzo P, Sánchez-Guerrero MC, Medrano E, García ML, Caparrós I, Giménez M, 2003: External greenhouse mobile shading: Effect on microclimate, water use efficiency and yield of a tomato crop grown under different salinity levels of the nutrient solution. Acta Horticulturae 609, 181-186.

López-Marín J, Gálvez A, González A, Egea-Gilabert C, Fernández JA, 2012: Effect of shade on yield, quality and photosynthesis-related parameters of sweet pepper plants. Acta Horticulturae 956, 545-552.

López-Marín J, González A, Pérez-Alfocea F, Egea-Gilabert C, Fernández JA, 2013: Grafting is an efficient alternative to shading screens to alleviate thermal stress in greenhouse-grown sweet pepper. Scientia Horticulturae 149, 39-46.

Martínez DLV, Ureña LJB, Aiz FDM, Martínez AL, 2016: Greenhouse Agriculture in Almería. A Comprehensive Techno-economic Analysis. Cajamar Caja Rural, pp. 1-408.

Marucci A, Cappuccini A, 2016a: Dynamic photovoltaic greenhouse: Energy efficiency in clear sky conditions. Applied Energy 170, 362-376.

Marucci A, Cappuccini A, 2016b: Dynamic photovoltaic greenhouse: Energy balance in completely clear sky condition during the hot period. Energy 102, 302-312.

Marucci A, Monarca D, Cecchini M, Colantoni A, Cappuccini A, 2015: Analysis of internal shading degree to a prototype of dynamics photovoltaic greenhouse through simulation software. Journal of Agricultural Engineering XLVI:483, 144-150.

National Astronomical Observatory of Japan. Sunrise/Sunset in
Matsue Japan from 21 February 2017 to 20 February 2018, http://eco.mtk.nao.ac.jp/koyomi/dni/2018/dni33.html.en (accessed 23 May 2017)

Pérez-Alonso J, Pérez-García M, Pasamontes-Romera M, Callejón-Ferre AJ, 2012: Performance analysis and neural modelling of a greenhouse integrated photovoltaic system. Renewable and Sustainable Energy Reviews 16, 4675-4685.

Sato N, Moriya H, Yasui K, Nonoshita T, 2013: Saving energy with a hybrid heating system using an air-to-air heat pump and oil heater in a rose greenhouse. Shokubutsu Kankyo Kogaku 25, 19-28.

Sonneveld PJ, Swinkels GLAM, Bot GPA, Flamand G, 2010a: Feasibility study for combining cooling and high grade energy production in a solar greenhouse. Biosystems Engineering 105, 51-58

Sonneveld PJ, Swinkels GLAM, Campen J, van Tuijl BAJ, Janssen HJJ, Bot GPA, 2010b: Performance results of a solar greenhouse combining electrical and thermal energy production. Biosystems Engineering 106, 48-57.

Sonneveld PJ, Swinkels GLAM, van Tuijl BAJ, Janssen HJJ, Campen J, Bot GPA, 2011: Performance of a concentrated photovoltaic energy system with static linear Fresnel lenses. Solar Energy 85, 432-442.

Souliotis M, Tripanagnostopoulos Y, Kavga A, 2006: The use of Fresnel lenses to reduce the ventilation needs of greenhouses. Acta Horticulturae 719, 107-114.

Taira K, Nakata J, 2010: Silicon cells: Catching rays. Nature Photonics Technology Focus 4, 602-603.

Tani A, Shiina S, Nakashima K, Hayashi M, 2014: Improvement in lettuce growth by light diffusion under solar panels. Journal of Agricultural Meteorology 70, 139-149.

Teitel M, Segal I, 1995: Net thermal radiation under shading screens. Journal of Agricultural Engineering Research 61, 19-26.

Ureña-Sánchez R, Callejón-Ferre ÁJ, Pérez-Alonso J, Carreño-Ortega Á, 2012: Greenhouse tomato production with electricity generation by roof-mounted flexible solar panels. Scientia Agricola 69, 233-239.

Vadiee A, Martin V, 2014: Enviro-economic assessment of energy conservation methods in commercial greenhouses in Iran. Outlook on Agriculture 45, 47-53.

Vadiee A, Yaghoubi M, 2016: Solar blind system- solar energy utilization and climate mitigation in glassed buildings. Energy Procedia 57, 2023-2032.

Yang F, Zhang Y, Hao Y, Cui Y, Wang W, Ji T, Shi F, Wei B, 2015: Visibly transparent organic photovoltaic with improved transparency and absorption based on tandem photonic crystal for greenhouse application. Applied Optics 54, 10232-10239.

Yano A, Furue A, Kadowaki M, Tanaka T, Hiraki E, Miyamoto M, Ishizu F, Noda S, 2009: Electrical energy generated by photovoltaic modules mounted inside the roof of a north-south oriented greenhouse. Biosystems Engineering 103, 228-238.

Yano A, Furue A, Moriyama T, Ide O, Tsuchiya K, 2007: Development of a greenhouse shading screen controller driven by photovoltaic energy. Journal of the Japanese Society of Agricultural Machinery 67, 100-110 (in Japanese with English abstract).

Yano A, Kadowaki M, Furue A, Tamaki N, Tanaka T, Hiraki E, Kato Y, Ishizu F, Noda S, 2010: Shading and electrical features of a photovoltaic array mounted inside the roof of an east-west oriented greenhouse. Biosystems Engineering 106, 367-377.

Yano A, Onoe M, Nakata J, 2014: Prototype semi-transparent photovoltaic modules for greenhouse roof applications. Biosystems Engineering 122, 62-73. 